\title{
KARAKTERISTIK SIMPLISIA TEH HITAM DARI TANAMAN Camelia sinensis Var. assamica DARI PERKEBUNAN TEH BALI CAHAYA AMERTA, DESA ANGSERI, KECAMATAN BATURITI, KABUPATEN TABANAN, BALI
}

\author{
N. L. P. V. Paramita*, N. M. D. Andani, I. A. P. Y. Putri, N. K. S. Indriyani, and N. M. P. \\ Susanti \\ Department of Pharmacy, Faculty of Mathematics and Natural Sciences, Universitas Udayana, \\ Bukit Jimbaran, Badung, Bali \\ *E-mail: vidya_paramita@unud.ac.id
}

\begin{abstract}
ABSTRAK
Teh hitam merupakan jenis teh yang dalam pengolahannya melalui proses fermentasi secara penuh. Karakteristik simplisia sangat dipengaruhi oleh tempat tumbuh tanaman tersebut. Suatu simplisia untuk dapat digunakan sebagai bahan baku, perlu dilakukan standardisasi salah satunya pengukuran karakterisasi simplisia untuk menjaga kualitas dan keamanannya. Tujuan penelitian ini adalah untuk mengetahui karakteristik simplisia teh hitam dari daun teh (Camellia sinensis var. assamica) yang berasal dari perkebunan teh Bali Cahaya Amertha, Desa Angseri, Kecamatan Baturiti, Kabupaten Tabanan, Bali. Karakterisasi simplisia dilakukan berdasarkan parameter standar tanaman teh pada Farmakope Herbal Indonesia yang meliputi pengamatan makroskopik, mikroskopik, susut pengeringan, kadar sari larut air, kadar sari larut etanol, kadar abu total, kadar abu tidak larut asam, kadar fenol total dan identifikasi katekin. Hasil penelitian menunjukkan bahwa simplisia teh hitam berbentuk lonjong memanjang dengan warna coklat kehitaman, tidak berbau, tidak berasa, lama kelamaan kelat, terdapat fragmen pengenal seperti serabut sklerenkim, epidermis bawah dengan stomata, makrosklerida, mesofil daun dengan berkas pengangkut, dan kristal kalsium oksalat bentuk roset. Hasil pengujian kadar sari larut air adalah $31,84 \% \pm 0,6446 \%$, kadar sari larut etanol 16,64\% $\pm 0,414 \%$, susut pengeringan 5,19\% $\pm 0,0902 \%$, kadar abu total 4,67\% $\pm 0,0392 \%$, kadar abu tidak larut asam $0,19 \% \pm 0,0025 \%$, kadar total fenol $0,9733 \% \pm 0,0189 \%$. Dari hasil penelitian ini dapat dilihat bahwa simplisia teh hitam ini telah memenuhi persyaratan karakteristik simplisia berdasarkan parameter yang tertera dalam Farmakope Herbal Indonesia.
\end{abstract}

Kata Kunci: Karakteristik simplisia, teh hitam, Camellia sinensis, Varietas assamica

\begin{abstract}
Black tea is a type of tea in such a way the polyphenols undergo a high degree of oxidation. The characteristics of simplicia are strongly influenced by the environment. In order to use a simplicia as an active ingredient, characterization test are required for maintaining the quality and safety. This study aimed to find out the characteristic of black tea simplicia from tea leaves (Camellia sinensis var. assamica) which were taken from Bali Cahaya Amerta Tea Plantation, Angseri Village, Baturiti Sub-district, Tabanan Regency, Bali. The characterization of the simplicia was done based on standard parameters of tea plant in Farmakope Herbal Indonesia including macroscopic test, microscopic test, the loss on drying, the contents of water soluble compound, ethanol soluble compound, total ash, acid insoluble ash, total phenol and the identification of cathecin. The results showed that black tea simplicia elongated shaped with blackish brown, odorless, tasteless, and there were fragments identifier such as sclerenkim fibers, epidermis with stomata, macrosklerida, leaf mesophyll with vascular tissue, and rosette calcium oxalate crystals. The result of the compounds content that dissolve in water was $31.84 \% \pm 0.6446 \%$, compounds content that dissolve in ethanol was $16.64 \% \pm 0.414 \%$, the loss on drying was $5.19 \% \pm 0.0902 \%$, total ash content was $4.67 \% \pm 0.0392 \%$, ash content that was insoluble in acid was $0.19 \% \pm 0.0025 \%$, and the total fenol content was $0.9733 \% \pm 0.0189 \%$. From the results, the black tea simplicia fulfills the requirements of simplicia characteristic based on Farmakope Herbal Indonesia parameter.
\end{abstract}

Keywords: Simplicia characteristics, black tea, Camellia sinensis, Variety of assamica 


\section{PENDAHULUAN}

Minuman telah dikenal dan digemari oleh masyarakat di seluruh dunia. Indonesia menjadi salah satu dari lima negara penghasil dan pengekspor teh utama di dunia. Terdapat 2 jenis varietas tanaman teh yaitu varietas assamica yang banyak tumbuh di Indonesia dan varietas sinensis yang ditemukan didaerah cina dan jepang. Jenis Teh varietas assamica memiliki kandungan katekin yang jauh lebih besar daripada varietas sinensis sehingga sangat berpotensi untuk dikembangkan menjadi bahan baku farmasi dan produk olahan pangan (Hartoyo, 2003).

Kandungan kimia yang terdapat pada daun teh yaitu senyawa teofilin, teobromin, kafein, polifenol, beberapa vitamin seperti vitamin B kompleks, C, dan E dan beberapa mineral seperti flour, kalsium, fosfor, stronsium, Mo, Zn, Fe, dan Mg. Senyawa polifenol utama pada daun teh yaitu katekin, yang terdiri dari epikatekin (EC), Epikatekin-3-gallat (ECG), epigallokatekin (EGC) dan epigallokatekin gallat (EGCG) (Budavari et al, 1996). Senyawa katekin ini memiliki aktivitas antioksidan dengan mekanisme meningkatkan enzim Glutathion-STransferase (GST) dan menangkap radikal bebas (Silalahi, 2002).

Terdapat 3 jenis teh yang dibedakan karena perbedaan dalam proses pengolahan daun teh, yaitu teh hijau (tanpa fermentasi), teh hitam atau teh merah (dengan fermentasi), dan teh oolong (semi fermentasi) (Radiana, 1985). Enzim yang berperan sangat penting dalam pengolahan teh hitam adalah polifenol oksidase. Pada tahap fermentasi katekin akan teroksidasi oleh enzim polifenol oksidase membentuk theaflavin dan thearubigin yang merupakan penentu kualitas teh hitam (Kunarto, 2005).

Theaflavin juga dilaporkan memiliki kemampuan protektif terhadap kanker dan kardiovaskuler, memiliki aktivitas antihipertensi, dan hipolipidemik selain juga dilaporkan sebagai antioksidan (Leung et al, 2001) Efek antioksidan pada theaflavin lebih kuat dibandingkan dengan vitamin $\mathrm{C}$, vitamin $\mathrm{E}$, propil galat $(\mathrm{PG})$, dan katekin teh hijau karena tingkat konstan theaflavin pada penangkapan radikal superoksida lebih tinggi (Wang C dan Li Y, 2006).

Ketersediaan bahan baku obat herbal yang berkualitas masih menjadi suatu masalah yang sering ditemui. Perbedaan kualitas suatu bahan baku daun teh (Camellia sinensis) dapat dipengaruhi oleh faktor genetik, cara penanaman, lokasi penanaman, variasi musiman yang diakibatkan oleh waktu pengumpulan dan cara pengolahan (Pravin, et al., 2012). Kandungan kimia yang terdapat dalam suatu tanaman sangat beragam dan luas. Belum adanya kontrol atau standar pada setiap tahapan preparasi suatu tanaman akan menyebabkan sulitnya mendapatkan bahan baku yang berkualitas. Perkebunan teh saat ini bisa kita dapatkan di daerah Bali. Produk teh yang dihasilkan dari perkebunan ini yaitu, teh hijau dan teh hitam. Untuk memenuhi jaminan kualitas terhadap bahan baku dari perkebunan teh Bali Cahaya Amertha maka diperlukan suatu standardisasi terhadap simplisianya.

Kunle, et al. (2012) menyebutkan bahwa standardisasi adalah proses penentuan set standar atau karakteristik inheren, parameter konstan, nilai kualitatif dan kuantitatif definitif yang menunjukkan jaminan kualitas, khasiat, keamanan dan reproduktifitas. Standardisasi obat baku herbal meliputi data paspor obat tanaman mentah, otentifikasi botani, pemeriksaan mikroskopis \& molekuler, identifikasi komposisi kimia dengan berbagai teknik kromatografi dan aktivitas biologis seluruh tanaman. Selain itu Evaluasi makroskopik serta profil kimia bahan herbal untuk pengendalian mutu dan standardisasi juga telah dilaporkan oleh berbagai penelitian (Coudhary and Sekhon, 2011).

Untuk mendapatkan jaminan akan kualitas daun teh, maka perlu dipenuhi suatu standar mutu produk dengan melakukan standardisasi sehingga efek farmakologi tanaman tersebut dapat terjamin. Dalam penelitian ini dilakukan standardisasi daun teh (Camellia sinensis) simplisia yang diambil dari perkebunan teh Bali Cahaya Amertha, Desa Angseri, Kecamatan Baturiti, Kabupaten Tabanan, Bali. Tujuan standardisasi adalah untuk menyusun parameter standardisasi dalam rangka menjamin mutu daun teh hitam yang dihasilkan dari perkebunan ini apabila ingin dilakukan pengembangan pembuatan obat herbal dengan bahan baku daun teh hitam. Sehingga diperoleh bahan baku teh hitam yang memenuhi syarat sesuai persyaratan karakteristik daunt teh yang tertuang dalam monografi monografi Farmakope Herbal Indonesia (FHI) yang diterbitkan oleh departemen kesehatan. Karena kita ketahui bahwa faktor tempat tumbuh dan geografi akan mempengaruhi kualitas suatu bahan baku. Parameter standardisasi yang tertuang dalam FHI 
untuk simplisia daun teh yaitu pengamatan makroskopik, mikroskopik, susut pengeringan, serta profil kadar sari larut air, kadar sari larut etanol, kadar abu total, kadar abu tidak larut asam, kadar fenol total dan identifikasi katekin.

\section{BAHAN DAN METODE}

\section{Bahan}

Bahan-bahan yang digunakan dalam penelitian ini adalah simplisia teh hitam (Camelia sinensis var. assamica) dari PT Bali Cahaya Amerta, Desa Angseri, Kecamatan Baturiti, Kabupten Tabanan, Bali, akuades, etanol pa (merck), kloroform pa (merck), $\mathrm{HCl}$ pa (merck), toluen pa (merck), kloralhidrat LP, asam galat (sigma), dan Folin-Ciocalteu Fenol LP (merck), aseton pa (merck), metanol pa (merck), asam format pa (merck), standar katekin dari Henan Senyuan Biological Technologi co.ltd.

\section{Peralatan}

Alat yang digunakan dalam penelitian ini adalah timbangan analitik, mikroskop, tanur, oven, desikator, spektrofotometri uv-vis.

\section{Prosedur Kerja}

\section{Pengambilan Daun Teh hitam}

Sampel teh hitam didapatkan dari Perkebunan Teh Bali Cahaya Amertha, Desa Angseri, Kecamatan Baturiti, Kabupaten Tabanan, Bali. Sampel teh hitam adalah Daun pucuk tanaman teh yang telah mengalami pengolahan yaitu pelayuan, penggilingan, fermentasi (oksidasi enzimatis), pengeringan.

\section{Pembuatan Serbuk Simplisia}

Simplisia teh hitam diserbuk dengan menggunakan blender dan diayak dengan ayakan no 60 .

\section{Uji Makroskopis}

Uji makroskopik bertujuan untuk menentukan ciri khas simplisia dengan pengamatan secara langsung organoleptis simplisia yaitu bentuk, warna, bau, dan rasa

\section{Uji Mikroskopis}

Uji mikroskopik mencakup pengamatan terhadap bagian simplisia dan fragmen pengenal dalam bentuk sel, isi sel atau jaringan tanaman serbuk simplisia yang dilakukan pengamatan di bawah mikroskop. Pemeriksaan mikroskopis simplisia daun Camellia sinensis dilakukan dengan pembuatan preparat terlebih dahulu. Preparat dibuat dengan cara meletakkan serbuk simplisia daun Camellia sinensis diatas kaca objek, ditambahkan dengan beberapa tetes kloralhidrat LP, kemudian ditutup dengan kaca penutup. Preparat diamati dibawah mikroskop dengan perbesaran kuat $125 \mathrm{x}$.

\section{Susut Pengeringan}

Ditimbang 1 g serbuk dalam botol timbang yang sebelumnya telah dipanaskan pada suhu $105^{\circ} \mathrm{C}$ selama 30 menit dan ditara. Serbuk dalam botol timbang diratakan dengan menggoyangkan botol, hingga merupakan lapisan setebal lebih kurang $5 \mathrm{~mm}$ sampai 10 $\mathrm{mm}$, dimasukkan ke dalam oven, dibuka tutupnya, dikeringkan pada suhu $105^{\circ} \mathrm{C}$ selama 30 menit hingga bobot tetap. Sebelum dipanaskan, botol dibiarkan dalam keadaan tertutup mendingin dalam desikator hingga suhu kamar. Hitung kadar dalam \% susut pengeringan.

\section{Kadar Sari Larut Air}

Ditimbang $5 \mathrm{~g}$ serbuk simplisia daun Camellia sinensis. Dimasukkan ke dalam labu bersumbat, ditambahkan $100 \mathrm{~mL}$ air jenuh kloroform, dikocok berkali-kali selama 6 jam lalu dibiarkan selama 18 jam. Disaring, diuapkan $20 \mathrm{ml}$ filtrat hingga kering dalam botol timbang yang telah ditara, dipanaskan sisa pada suhu 105 ${ }^{0} \mathrm{C}$ hingga bobot tetap. Dihitung kadar dalam persen sari yang larut dalam air, dihitung terhadap bahan awal (Kemenkes RI, 2011). Kadar sari larut air dihitung dengan menggunakan persamaan berikut.

$$
\%=\frac{\mathrm{W} 2-\mathrm{W} 0}{\mathrm{~W} 1-\mathrm{W} 0} \times \frac{100}{20} \times 100 \%
$$

Keterangan:

$\mathrm{W} 0=$ Bobot cawan kosong

$\mathrm{W} 1$ = Bobot cawan + sampel yang digunakan

$\mathrm{W} 2$ = Bobot cawan + hasil pengeringan 


\section{Kadar Sari Larut Etanol}

Ditimbang $5 \mathrm{~g}$ serbuk simplisia daun Camellia sinensis. Dimasukkan kedalam labu bersumbat, ditambahkan $100 \mathrm{~mL}$ etanol (95\%), dikocok berkali-kali selama 6 jam pertama dan kemudian dibiarkan selama 18 jam. Disaring dan diuapkan $20 \mathrm{~mL}$ filtrat hingga kering dalam botol timbang yang telah ditara, dipanaskan sisa pada suhu $105{ }^{\circ} \mathrm{C}$ hingga bobot tetap. Dihitung kadar dalam persen sari yang larut dalam etanol (95\%) dihitung terhadap bahan awal (Kemenkes RI, 2011). \% kadar sari larut etanol dihitung dengan menggunakan persamaan berikut.

$$
\%=\frac{\mathrm{W} 2-\mathrm{W} 0}{\mathrm{~W} 1-\mathrm{W} 0} \times \frac{100}{20} \times 100 \%
$$

Keterangan:

$\mathrm{W} 0=$ Bobot cawan kosong

$\mathrm{W} 1$ = Bobot cawan + sampel yang digunakan

$\mathrm{W} 2=$ Bobot cawan + hasil pengeringan

\section{Kadar Abu Total}

Ditimbang 2 g serbuk dimasukkan ke dalam krus silikat yang telah dipijar dan ditara, dipijarkan perlahan-lahan pada suhu $600^{\circ} \mathrm{C}$ hingga arang habis, kemudian didinginkan dan ditimbang hingga bobot tetap. Kadar abu total dihitung terhadap berat bahan uji, dinyatakan dalam \%b/b (Kemenkes RI, 2011).

\section{Kadar Abu Tidak Larut Asam}

Abu yang telah diperoleh pada penetapan kadar abu, dididihkan dengan $25 \mathrm{~mL}$ asam klorida encer $\mathrm{P}$ selama 5 menit, dikumpulkan bagian yang tidak larut dalam asam. Kemudian disaring melalui kertas saring bebas abu, dicuci dengan air panas, dipijarkan hingga bobot tetap pada suhu $600^{\circ} \mathrm{C}$, ditimbang. Dihitung kadar abu yang tidak larut dalam asam terhadap berat bahan uji, dinyatakan dalam $\% \mathrm{~b} / \mathrm{b}$ (Kemenkes RI, 2011).

\section{Kadar Fenol Total}

Ditimbang sejumlah serbuk simplisia, masukkan ke dalam labu ukur, encerkan secara kuantitatif dan bertahap dengan metanol $\mathrm{P}$ hingga kadar tertentu. Ditimbang sejumlah asam galat, dimasukkan ke dalam labu ukur, encerkan secara kuantitatif dan bertahap dengan metanol P hingga kadar lebih kurang $1 \mathrm{mg} / \mathrm{ml}$. Diencerkan hingga kadar berturut-turut 5;15;30;50;70;100 bpj $(\mathrm{ppm}=\mathrm{mg} / \mathrm{L}=\mu \mathrm{g} / \mathrm{mL})$. Pada masing-masing
$1 \mathrm{~mL}$ larutan uji dan enceran larutan pembanding dalam tabung reaksi, tambahkan $5 \mathrm{~mL}$ enceran Folin-Ciocalteu Fenol LP (7,5\% dalam air). Diamkan selama 8 menit, tambahkan $4 \mathrm{~mL}$ Na2SO4 1\%, inkubasi selama 1 jam. Ukur serapan masing-masing larutan pada panjang gelombang serapan maksimum lebih kurang 730 nm. Dibuat kurva kalibrasi (Kemenkes RI, 2011).

\section{Identifikasi katekin}

Identifikasi pola kromatografi lapis tipis dengan Fase diam silika gel $60 \mathrm{~F}_{254}$ dan Fase gerak Toluen P-Aseton P-asam format P (5:4:1 $\mathrm{v} / \mathrm{v})$. Larutan pembanding katekin $2 \%$ dalam metanol P. Kosentrasi larutan uji sampel serbuk simplisia teh hitam 20\% dalam Metanol P. Volume penotolan larutan uji $10 \mu \mathrm{L}$ dan larutan pembanding $5 \mu \mathrm{L}$. Deteksi senyawa katekin dari larutan uji dengan sinar tampak, $\mathrm{UV}_{254}$ dan $\mathrm{UV}_{366}$ (Kemenkes RI, 2011).

\section{HASIL DAN PEMBAHASAN}

Karakterisasi simplisia berarti bahwa simplisia yang akan digunakan untuk bahan baku obat harus memenuhi persyaratan monografi yang tertuang dalam Farmakope Herbal Indonesia (Depkes RI, 2000).

Hasil penetapan makroskopis dan mikroskopis simplisia daun teh hitam (Camellia sinensis var. assamica) dapat dilihat pada tabel 1 dan tabel 2. Pengamatan makroskopis dan mikroskopis dari simplisia teh hitam telah sesuai dengan karakteristik organoleptis dan mikroskopis dari simplisia daun teh Camelia sinensis yang tertuang dalam FHI. Gambar fragmen pengenal mikroskopis dalam simplisia teh hitam dapat dilihat pada Gambar 1.

Teh hitam berasal dari tanaman daun teh yang dalam proses pengolahannya dilakukan fermentasi penuh terhadap daun teh. Fermentasi terjadi oleh karena adanya enzim polifenol oksidase. Proses fermentasi ini menyebabkan adanya perubahan jumlah katekin dalam teh hijau yang teroksidasi menjadi bentuk senyawa lain yaitu theaflavin dan thearubigin (Anjarsari, 2016). 
Tabel 1. Hasil Karakterisasi Makroskopis Simplisia Teh Hitam dari Perkebunan Teh Bali Cahaya Amertha

\begin{tabular}{|c|c|c|}
\hline Penetapan & $\begin{array}{l}\text { Referensi mutu } \\
\text { teh dalam FHI }\end{array}$ & $\begin{array}{l}\text { Hasil } \\
\text { penelitian }\end{array}$ \\
\hline \multicolumn{3}{|l|}{ Makroskopis } \\
\hline Bentuk & $\begin{array}{l}\text { bulat telur } \\
\text { memanjang } \\
\text { sampai jorong }\end{array}$ & Lonjong \\
\hline Warna & Hijau tua & $\begin{array}{l}\text { Coklat } \\
\text { kehitaman }\end{array}$ \\
\hline $\mathrm{Bau}$ & Tidak berbau & Tidak berbau \\
\hline Rasa & $\begin{array}{l}\text { Tidak berasa } \\
\text { lama kelamaan } \\
\text { kelat }\end{array}$ & Tidak berasa \\
\hline
\end{tabular}

Identifikasi makroskopis dan mikroskopis dalam penelitian ini menunjukkan bahwa proses pengolahan simplisia teh hitam tidak akan merubah karakteristik organoleptis dan keberadaan fragmen pengenal dari daun teh. Proses fermentasi hanyalah merubah komposisi kandungan kimia dari simplisia teh hitam. Rasa simplisia daun teh hitam tidak berasa kelat, dapat disebabkan karena kadar katekin yang berkurang akibat proses fermentasi. Senyawa katekin dan derivatnya dalam daun teh memberi rasa kelat/pahit. Warna simplisia the hitam berwarna coklat kehitaman karena adanya proses oksidasi daun teh.

Katekin dalam daun teh merupakan komponen utama penentu mutu daun teh yang akan mempengaruhi rasa, warna dan aroma. Pada proses pembuatan teh hitam, daun the dipotong menjadi bagian bagian yang kecil agar enzim polifenol oksidase dapat mengoksidasi katekin yang ada di vakuola. Proses oksidasi dikenal dengan proses fermentasi yaitu perubahan monomer flavan-3-ol menjadi thearubigin dan theaflavin (polimerisasi). Kualitas the hitam ditentukan oleh keberadaan senyawa theaflavin. Jenis senyawa Theaflavin pada teh hitam akan ditentukan oleh komposisi katekin (flavan-3-ol) (Wright et al., 2002 dalam Mitrowihardjo, 2012). Terdapat empat jenis theaflavin yaitu nongallated theaflavin (TF), mono-gallated theaflavin (TF-3g dan TF-3'g), dan digallated theaflavin (TF-3,3'dg) (Menet et al., 2004 cit Mitrowihardjo, 2012).
Tabel 2. Karakterisasi Mikroskopis Simplisia Teh Hitam dari Perkebunan Teh Bali Cahaya Amertha

\begin{tabular}{|c|c|c|}
\hline Penetapan & $\begin{array}{l}\text { Referensi mutu } \\
\text { teh dalam FHI }\end{array}$ & $\begin{array}{l}\text { Hasil } \\
\text { Penelitian }\end{array}$ \\
\hline \multirow[t]{8}{*}{$\begin{array}{l}\text { Mikroskopi } \\
\text { Fragmen } \\
\text { pengenal }\end{array}$} & $\begin{array}{l}\text { Kristal kalsium } \\
\text { oksalat bentuk } \\
\text { roset }\end{array}$ & Ada \\
\hline & $\begin{array}{l}\text { Epidermis atas } \\
\text { dengan rambut } \\
\text { penutup }\end{array}$ & Tidak ada \\
\hline & Makrosklereida & Ada \\
\hline & $\begin{array}{l}\text { Serabut } \\
\text { sklerenkim }\end{array}$ & Ada \\
\hline & Epidermis Atas & Ada \\
\hline & $\begin{array}{l}\text { Mesofil daun } \\
\text { dengan berkas } \\
\text { pengangkut dan } \\
\text { bintik kelenjar }\end{array}$ & Ada \\
\hline & $\begin{array}{l}\text { Epidermis } \\
\text { bawah dengan } \\
\text { stomata }\end{array}$ & Ada \\
\hline & $\begin{array}{l}\text { Berkas } \\
\text { pengangkut } \\
\text { penebalan spiral }\end{array}$ & Ada \\
\hline
\end{tabular}

Hasil uji susut pengeringan pada penelitian ini diperoleh hasil kadar susut pengeringan sebesar 5,19 $\pm 0,0902 \%$ (tabel 3). Nilai tersebut telah memenuhi syarat standar pada FHI (Farmakope Herbal Indonesia) dimana nilai dari susut pengeringan simplisa daun teh tidak lebih dari 10\% (Depkes RI 2000). Tujuan penetapan susut pengeringan adalah untuk mengetahui batas maksimal hilangnya senyawa yang mudah menguap pada suhu $105^{\circ} \mathrm{C}$ yaitu air dan senyawa lainnya. Sehingga dapat dikatakan bahwa kadar susut pengeringan menandakan kadar kelembaban suatu sampel terkait dengan proses pengeringan dari suatu teh hitam yang dilakukan dalam perusahaan tersebut. 
Apabila kadar lembab atau jumlah air tinggi atau tingginya nilai susut pengeringan akan memicu terjadinya pembusukan bahan teh oleh karena jamur dan bakteri. Keberadaan air juga memungkikan akan menyebabkan terjadinya perusakan senyawa aktif oleh enzim. Sharma et al (2011) dan Abdolmaleki (2016) melaporkan adanya variasi kadar kelembaban dari teh hitam yang bervariasi dari sampel teh hitam yang diambil dari daerah yang berbeda. Kadar lembab pada 5 daerah di Iran bagian utara menunjukkan kadar diantara 4,27 sampai dengan $5,83 \%$. Kadar lembab pada 3 merek teh hitam dari India yaitu 3,63 sampai dengan 3,76\%.

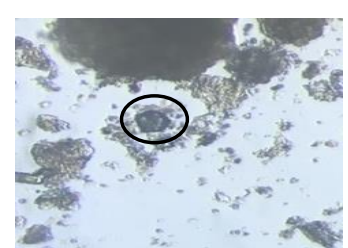

(a)

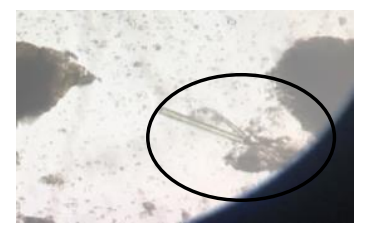

(c)

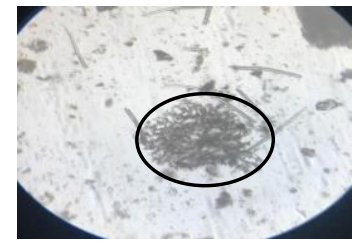

(e)

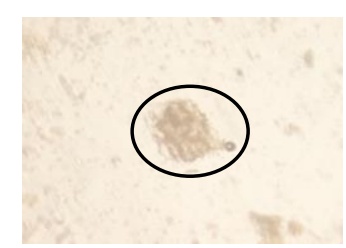

(b)

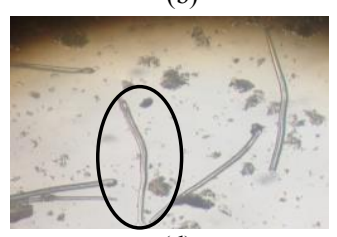

(d)

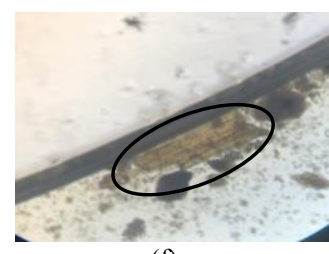

(f)
Gambar 1. Fragmen mikroskopis simplisia teh hitam, keterangan; a) kristal kalsium oksalat bentuk roset; b) epidermis atas dengan rambut penutup; c) mikrosklerida; d) serabut sklerenkim; e) epidermis atas; mesofil daun dengan berkas pengangkut dan bintik kelenjar.

Penetapan uji kadar sari larut etanol dan air dilakukan untuk memberikan gambaran kadar persentase senyawa yang dapat tersari dengan menggunakan pelarut etanol dan air suatu simplisia (Depkes RI, 2000). Penggunaan dua pelarut tersebut karena keduanya merupakan cairan pelarut yang diperbolehkan dan memenuhi syarat kefarmasian (pharmaceutical grade). Pelarut air dimaksudkan untuk melarutkan senyawa polar dan etanol untuk melarutkan senyawa kurang polar jika dibandingkan dengan pelarut air yang terdapat dalam sampel (Sudarmadji dkk., 1986). Hasil perolehan diperoleh kadar sari larut etanol sebesar 16,64 $\pm 0,414$ dan kadar sari larut air sebesar 31,84 $\pm 0,6446$ (Tabel 2). Nilai tersebut telah memenuhi persyaratan pada FHI (Farmakope Herbal Indonesia) dimana nilainya tidak kurang dari nilai syarat yang ditetapkan dalam monografi tersebut.

Tabel 3. Hasil Karakterisasi Kuantitatif dari Simplisia Teh Hitam dari Perkebunan Teh Bali Cahaya Amertha

\begin{tabular}{|c|c|c|}
\hline Penetapan & $\begin{array}{l}\text { Referensi } \\
\text { mutu teh } \\
\text { dalam FHI }\end{array}$ & Hasil penelitian \\
\hline $\begin{array}{l}\text { Susut } \\
\text { pengeringan }\end{array}$ & $\begin{array}{l}\text { tidak lebih } \\
\text { dari } 10 \%\end{array}$ & $5,19 \pm 0,0902 \%$ \\
\hline $\begin{array}{l}\text { Kadar Sari } \\
\text { Larut Air }\end{array}$ & $\begin{array}{l}\text { tidak } \\
\text { kurang } \\
\text { dari } 8,4 \%\end{array}$ & $31,84 \pm 0,6446 \%$ \\
\hline $\begin{array}{l}\text { Kadar Sari } \\
\text { Larut Etanol }\end{array}$ & $\begin{array}{l}\text { tidak } \\
\text { kurang } \\
\text { dari } 4,5 \%\end{array}$ & $16,64 \pm 0,414 \%$ \\
\hline Kadar Abu & & $4,67 \pm 0,0392 \%$ \\
\hline $\begin{array}{l}\text { Kadar Abu } \\
\text { tidak larut } \\
\text { asam }\end{array}$ & $\begin{array}{l}\text { tidak lebih } \\
\text { dari 5,6\% } \\
\text { tidak lebih } \\
\text { dari } 0,6 \%\end{array}$ & $0,19 \pm 0,0025 \%$ \\
\hline $\begin{array}{l}\text { Kadar fenol } \\
\text { total }\end{array}$ & $\begin{array}{l}\text { Tidak } \\
\text { kurang } \\
\text { dari } \\
0,51 \% \\
\text { dihitung } \\
\text { sebagai } \\
\text { asam galat }\end{array}$ & $0,9733 \pm 0,0189 \%$ \\
\hline
\end{tabular}

Pengukuran kadar sari larut air dan kadar sari larut etanol tentu saja akan menghasilkan variasi kadar apabila sampel teh hitam yang diukur berasal dari daerah tumbuh yang berbeda karena terkait keberadaan senyawa polar dan nonpolar pada sampel tersebut. Daerah pertumbuhan yang berbeda akan menghasilkan perbedaan persentase komposisi senyawa kandungan kimia yang terkandung didalam suatu tanaman. Keberadaan senyawa marker dari teh hitam dalam hal ini katekin, theaflavin dan thearubigin akan selalu ada dalam teh hitam 
yang ditumbuhkan dari lokasi yang berbeda. Kadar sari larut air dari teh hitam yang berasal dari 5 daerah berbeda di Iran bagian Utara menghasilkan kadar sari larut air yang bervariasi yaitu 37,02 sampai dengan $41,07 \%$ (Abdolmaleki, 2016). Owuor et al (1986) memperkirakan kadar sari larut air dari teh hitam dari berbegai negara berbeda beda yaitu China $36,79 \%$, India $36,89-41,95 \%$, Kenya $44,12 \%$ dan Srilanka 36,72 sampai dengan 46,90\%. Sharma et al (2011) melaporkan kadar sari larut etanol dari 3 merek teh hitam yang dijual di Pasar lokal India yaitu Brooke Bond Red Label, Tata Premium and Duncan Double Diamond yaitu berturut turut $12,64 \%, 12,67 \%$, dan $12,62 \%$. Sedangkan kadar sari larut air dari ketiga merek tersebut berturut turut $23,04 \%$, $23,06 \%$, dan 23,03\%. Tata Premium memiliki hasil kadar sari larut etanol dan kadar sari larut air yang paling tinggi diantara 2 merek lainnya. Hal ini menunjukkan bahwa faktor lokasi tempat tumbuh akan mempengaruhi jalur biosintesis dan kadar dari metabolit sekunder dalam suatu tanaman.

Pengukuran Kadar abu total juga dapat bertujuan mengetahui kandungan mineral eksternal dan internal berasal dari proses pengolahan simplisia. Jenis mineral yang terdapat dalam suatu bahan terdiri dari garamgaram anorganik (fosfat, karbonat, klorida, sulfat nitrat dan logam alkali) dan garam-garam organik (garam dari asam malat, oksalat, asetat, pektat dan lain-lain) dan (Pine dkk., 2015). Hasil penetapan kadar abu total pada penelitian ini yaitu sebesar 4,67 $\pm 0,0392$. Nilai tersebut telah memenuhi persyaratan pada FHI (Farmakope Herbal Indonesia). Dimana nilai kadar abu total tidak lebih dari 5,6\%. Nilai kadar abu yang tinggi dan melebihi batas persyaratan FHI memberikan indikasi adanya kontaminasi, substitusi, pemalsuan atau ketidaktelitian dalam mempersiapkan daun teh hitam yang akan dipasarkan. Penetapan uji kadar abu tidak larut asam terkait dengan kebersihan dan kemurnian dari bahan tersebut, selain juga merupakan berarti besaran kandungan mineral dalam suatu bahan (Husna dkk., 2014). Nilai kadar abu larut asam juga dapat diartikan adanya kontaminasi silikat seperti tanah dan pasir. Kadar abu tidak larut asam dilakukan dengan melarutkan hasil abu total dengan pelarut asam. Abu yang tidak larut asam dihitung sebagai kadar abu tidak larut asam. Pada penelitian ini diperoleh kadar abu tidak larut asam yang telah memenuhi persyaratan pada FHI yaitu sebesar 0,19 \pm $0,0025 \%$, dimana FHI menyatakan nilai kadar abu tidak larut asam tidak lebih dari 0,6\%. Perbedaan lokasi pertumbuhan dari tanaman teh akan menghasilkan nilai kadar abu yang bervariasi. Penelitian Abdolmaleki (2016) melaporkan 5 daerah tumbuh yang berbeda dari teh hitam di bagian utara Iran menunjukkan nilai kadar abu total yang bervariasi dari 5,50 sampai dengan $6,30 \%$. Penelitian ini juga berkolerasi dengan penelitian Sharma et al (2011) yang melaporkan nilai kadar abu total dan kadar abu tidak larut asam yang bervariasi dari 3 merek teh hitam Brooke Bond Red Label, Tata Premium and Duncan Double Diamond. Nilai kadar abu total dari ketiga merek tersebut berturut turut $(8,60 \%, 8,66 \%$, dan 8,55\%) sedangkan nilai kadar abu tidak larut asam dari ketiga merek tersebut berturut turut $(1,33 \%, 1,36 \%$, dan $1,31 \%)$.

Uji total fenol bertujuan untuk menetapkan kadar fenol dalam sampel. Metode yang digunakan adalah metode Follin-Ciocalteu yang mengunakan spektrofotometri sinar tampak. Pada proses ini terbentuk senyawa kompleks berwarna biru yang berasal dari reduksi fosfomolibdat-fosfotungsat oleh senyawa fenolik. Kadar total fenol pada serbuk teh hitam dinyatakan sebagai ekuivalen asam galat atau Gallic Acid Equivalent (GAE). Kadar total fenol yang terdapat pada simplisia serbuk teh hitam adalah $0,9733 \pm 0,0189 \%$. Nilai kadar total fenol telah memenuhi nilai yang tertuang dalam FHI yaitu tidak kurang dari $0.51 \%$ jika dihitung sebagai asam galat (Tabel 3). Senyawa kimia yang terkandung dalam daun teh terdiri dari kelompok fenol, bukan fenol, enzim dan senyawa aromatis. Kelompok senyawa fenol yang terkandung dalam simplisia teh hitam yaitu kelompok katekin dan senyawa kimia theaflavin dan therubigin yang berasal dari polimerisasi katekin (flavan-3-ol). Abdolmaleki (2016) melaporkan bahwa kadar total fenol dari 5 daerah yang berbeda di Iran bagian utara menghasilkan kadar bervariasi yaitu dari 12,20 s/d 17,10 g/100g. perbedaan ini dapat disebabkan oleh perbedaan waktu fermentasi pasca panen dari daun teh.

Proses fermentasi senyawa katekin tidak $100 \%$ menghilangkan jumlah katekin yang ada pada simplisia teh hitam. Karori et al (2007) melaporkan bahwa kadar katekin pada simplisa teh hitam terdegradasi sebanyak 57,70 \% sehingga kadar katekin setelah pengolahan pada 
teh hitam tersisa 5,91 \%. Sehingga dalam identifikasi kandungan kimia katekin digunakan sebagai standar pembanding untuk melihat keberadaan senyawa katekin. Hasil identifikasi kimia menggunakan pola kromatografi ditunjukkan pada Gambar 2.

Senyawa katekin pada sinar $\mathrm{UV}_{254}$ tampak dengan jelas dan letak senyawa katekin pada penelitian ini telah sesuai dengan pola kromatografi pada FHI yaitu pada Rf 0,5.

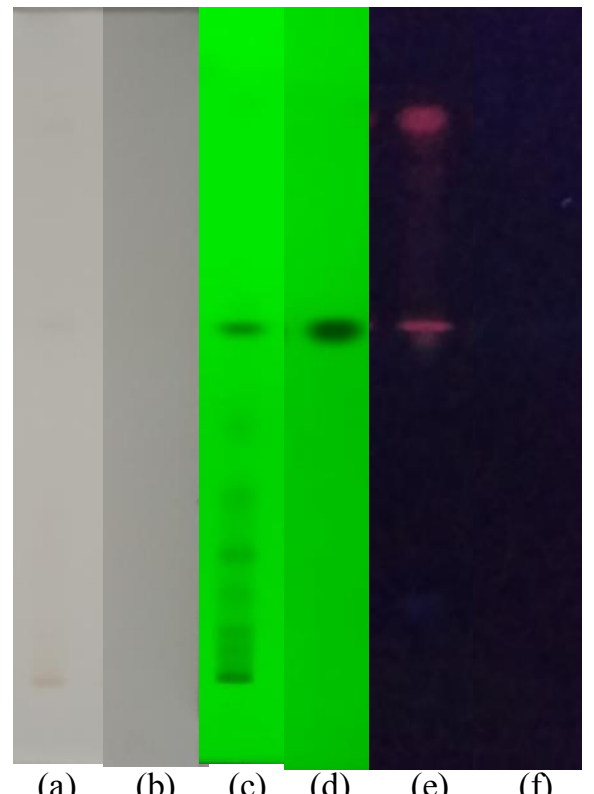

Gambar 2. Pola kromatografi serbuk simplisia teh hitam. a) serbuk teh hitam pada sinar tambak; b) katekin pada sinar tampak; c) serbuk teh hitam pada sinar $\mathrm{UV}_{254}$; d) katekin pada sinar $\mathrm{UV}_{254}$; e) serbuk teh hitam pada sinar $\mathrm{UV}_{366} ; \mathrm{f}$ ) katekin pada sinar $\mathrm{UV}_{366}$.

\section{SIMPULAN}

Hasil karakterisasi simplisia teh hitam (Camellia sinensis var. assamica) dari dari perkebunan teh Bali Cahaya Amertha, Desa Angseri, Kecamatan Baturiti, Kabupaten Tabanan, Bali telah memenuhi persyaratan bahan baku obat berdasarkan Farmakope Herbal Indonesia. Adapun saran yang dapat diberikan pada penelitian selanjutnya adalah perlu dilakukan penelitian lebih lanjut untuk pengujian parameter standardisasi simplisia teh hitam (Camellia sinensis var. assamica) lainnya seperti uji residu pestisida, cemaran logam berat, dan cemaran mikroba.

\section{UCAPAN TERIMA KASIH}

Penulis mengucapkan terimakasih kepada semua pihak yang telah membantu dalam penelitian ini khususnya perkebunan teh bali Cahaya Amertha atas kerjasamanya dalam perolehan sampel daun teh.

\section{DAFTAR PUSTAKA}

Adolmaleki, F., 2016, Chemical Analysis and Charateristics of Black Tea Produced in North of Iran, Journal of Food Biosciences and Technology, 6(1): 23-32

Anjarsari I.R.D., 2016, Katekin the Indonesia: Prospek dan manfaatnya, Jurnal Kultivasi, 15(2): 99-106

Budavari and Susan, 1996, The Merck Index: An Encyclopedia of Chemical, Drug, and Biologicals, Twelfth Edition, Merck \& Co., Inc., New Jersey.

Depkes RI, 2000, Parameter Standar Umum Ekstrak Tumbuhan Obat, Direktorat Jenderal Pengawasan Obat dan Makanan, Jakarta.

Direktorat pengolahan dan pemasaran hasil perkebunan, 2017, Pedoman dan penanganan pasca panen tanaman Teh, Cetakan 1, Direktorat Jenderal Perkebunan, Kementerian Pertanian

Hartoyo, A., 2003, Teh dan Khasiatnya Bagi Kesehatan, Penerbit Kanisius, Yogyakarta.

Husna, N. E., Asmawati, dan G. Suwarjana, 2014, Dendeng Ikan Leubiem (Canthidermis maculatus) dengan Variasi Metode Pembuatan, Jenis Gula, dan Metode Pengeringan, Jurnal Teknologi dan Industri Pertanian Indonesia, 6(3): 76-81.

Kemenkes RI, 2011, Suplemen II Farmakope Herbal Indonesia, Edisi I, Kementrian Kesehatan Republik Indonesia, Jakarta.

Kunarto, B., 2005, Teknologi Pengolahan Teh Hitam (Camellia sinensis L. Kuntze) Sistem Orthodox, Semarang University Press, Semarang. 
Leung, L.K., Su Y., Chen R., Zang Z., Huang Y. and Chen Z., 2001, Theavlavin in Black Tea and Catechin in Green Tea are Equally Effective Antioxidant, The Journal Nutrition, 131(1): 2248-2251

Mitrowihardjo S. 2012. Kandungan katekin dan hasil pucuk beberapa klon teh (Camelia sinensis (L.) O. Kuntze) unggulan pada ketinggian yang berbeda di kebun Pagilaran. Disertasi Program Studi Pemuliaan Tanaman. Fakultas Pertanian UGM. Yogyakarta

Owuor, P. O., Horita, H., Tsushida, T., dan Murai, T., 1986, Comparison of the chemical composition of black teas from main black tea producing parts of the world. Tea, 7: 71-78

Pine, A. T. D., G. Alam, dan F. Attamim, 2015, Standardisasi Mutu Ekstrak Daun Gedi (Abelmoschus manihot (L.) Medik) Dan Uji Efek Antioksidan dengan Metode DPPH, JK FIK UINAM 3(3):111-128

Rohdiana, D., 2015, Teh: Proses, karakteristik, dan komponen fungsionalnya, Foodreview Indonesia, 10(8): 34-37
Silalahi and Jansen, 2002, Senyawa Polifenol Sebagai Komponen Aktif yang Berkhasiat Dalam Teh, Majalah Kedokteran Indonesia.

Sharma, P.K., Ali, M., dan Yadav, D.K., 2011, Physicochemical and Phytochemical Evaluation of Different Black Tea Brands, Journal of Applied Pharmaceutical Science, 1(3): 121-124

Sudarmadji, S., Haryono, B., dan Suhardi, 1986, Analisa Bahan Makanan dan Pertanian, Penerbit Liberty, Yogyakarta.

Wang C and Li Y., 2006, Research Progress on Property and Application of Theaflavin, African Journal of Botechnology, 5(3): 213-218. 